Israel, P. (2017). Mueda massacre: the musical archive. Journal of Southern African Studies,

\title{
Mueda massacre: the musical archive
}

\author{
Paolo Israel
}

\begin{abstract}
As in Pidjiguiti in Guiné-Bissau or Baixa de Cassanje in Angola, the massacre that occurred in the northern Mozambican town of Mueda on 16 June 1960 has been inscribed in the nationalist narrative as the breaking point of anti-colonial unrest and the trigger of the armed liberation struggle. In the past 20 years several scholars have questioned the central tenets of the nationalist interpretation, especially the idea that the aim of the demonstration was political independence - a claim considered too lofty to be articulated by a mass of illiterate peasants guided by leaders enmeshed in ethnic organisations. Caught between the rhetorics of resistance and revisionism, the colonial archive and oral testimony, the event itself has been rendered illegible. To rescue 16 June from such deadlock, this article turns towards a different kind of historical material: song. Proceeding archaeologically, it moves from songs that reproduce the official version; through more ancient songs, which express some direct experience of the event, however layered and reformulated; to songs that were sung at the time of the massacre. These songs and the echoes they elicit from other sources pave the way to a re-interpretation of the event: from the point zero of a vanguardist history of national consciousness, to a utopian moment in which independence appeared as a possibility, however unclearly understood, the political imagination expanding beyond any consideration of objective constraint.
\end{abstract}

Perhaps no event in the history of Mozambican anti-colonial resistance has been so shrouded in the mists of nationalism as the Mueda massacre of 16 June 1960. The myth was inscribed through the eyewitness testimony of Alberto Joaquim Chipande - then deputy chief commander of the liberation army and later Minister of Defence - reproduced in Eduardo Mondlane's Struggle For Mozambique with words still resonant with orality:

[c]ertain leaders worked amongst us. Some of them were taken by the Portuguese - Tiago Muller, Faustino Vanomba, Kibiriti Diwane - in the massacre at Mueda on 16 June 1960. How did that happen? Well, some of these men had made contact with the authorities and asked for more liberty and more pay ... After a while, when people were giving support to these leaders, the Portuguese sent police through the villages inviting people to a meeting at Mueda. Several thousand people came to hear what the Portuguese would say. As it turned out, the administrator had asked the governor of Delgado Province to come from Porto Amelia and to bring a company of troops. But these troops were hidden when they got to Mueda. We didn't see them at first. 
Then the governor invited our leaders into the administrator's office. I was waiting outside. They were in there for four hours. When they came out on the verandah, the governor asked the crowd who wanted to speak. Many wanted to speak, and the governor told them all to stand on one side.

Then without another word he ordered the police to bind the hands of those who had stood on one side, and the police began beating them. I was close by. I saw it all. When the people saw what was happening, they began to demonstrate against the Portuguese, and the Portuguese simply ordered the police trucks to come and collect these arrested persons. So there were more demonstrations against this. At that moment the troops were still hidden, and the people went up close to the police to stop the arrested persons from being taken away. So the governor called the troops, and when they appeared he told them to open fire. They killed about 600 people. ${ }^{1}$

The following year Chipande published a longer formal account in the magazine Mozambique Revolution, which detailed the order of the visits of the leaders coming from Tanganyika in the months preceding the massacre; specified their affiliation to the Mozambique African National Union (MANU), a mutual help association of migrants in Tanganyika mainly composed of Makonde people; spelled out the leaders' request to the administrator - negotiating the independence of Mozambique; and described the unfolding of the events, from the administrator's arrogant and unsatisfying address to the savage shooting and grenade- throwing by Portuguese soldiers. ${ }^{2}$

The events of 16 June 1960 would then be the object of Mozambique's first feature film: Ruy Guerra's Mueda Memória e Massacre. This stunning feat of genre-blending intersperses the live shooting of a popular theatrical representation of the massacre with testimonies of survivors. 3 The first half of the theatre piece is structured around the repetition of the same sequence. A delegation of migrants from Tanganyika, well dressed and dignified to the point of sadness, arrives at the administrative seat of Mueda and demands to see the administrator; they are ordered to wait outside the building and subjected to the ordinary humiliating rituals of colonialism, after which they are allowed inside and interrogated by the administrator with regard to the purpose of their visit. 'We come to reclaim independence'. 'What do you know about independence? It would be better to give it to monkeys than to you negroes! Don't you know we cut your tails and made you into persons?' The pleaders insist but the dialogue soon dies off; the first delegation is sent back, the second flogged and arrested. Finally the administrator agrees to hold a public meeting in which the demands of the last delegation will be addressed to the provincial governor, summoned for the occasion. A large

\footnotetext{
${ }^{1}$ E. Mondlane, The Struggle for Mozambique (London, Penguin, 1969), p. 117. This essay takes for granted general knowledge of the history of Mozambican nationalism and Frelimo. For an introduction to the problematics, see J.P. Borges Coelho, 'Politics and Contemporary History in Mozambique: A Set of Epistemological Notes', Kronos, 39, 1 (2013), pp. $20-31$.

2 J.A. Chipande, '16 June 1960-1970: The Mueda Massacre', Mozambique Revolution, 43 (1970), pp. 12-14.

${ }^{3}$ I viewed the version of the film restored in O Mundo em Imagens: Filmes do Arquivo do Instituto Nacional de Audiovisual e Cinema (Bayreuth and Maputo, IWALEWA and INAC, 2012). For a close reading, see R. Schefer, 'La Forme-evénement: Le cinéma révolutionnaire Mozambicain et le cinéma de libération’ ( $\mathrm{PhD}$ thesis, Paris Sorbonne 3, 2015), pp. 309-585. See also J.P. Borges Coelho's insightful notes in the booklet of O Mundo em Imagens, pp. 4-5.
} 
crowd assembles outside the building to hear the outcome of the conversation. Inside, the request for independence is again rejected by the Governor, who then walks out to address the crowd, promising the lowering of prices and the bettering of conditions. The crowd boos him: 'this is not what we came for! We want Independence!' Two seditious migrants from Tanganyika, Faustino Vannomba and Mateus 'Shibiliti' Waduvani, are arrested and put into a jeep to be carried away; the crowd rebels, holding the jeep and hurling stones; the colonial policemen open fire and the people fall. 4

More than Vannomba's composed testimony in Kiswahili, or the account of an allegorical old peasant crouching besides the skeleton of a hut in construction, or the cathartic selfincrimination of a colonial policeman - a foreboding of the 'meeting of the compromised' that Guerra himself would document shortly thereafter - it is the syncopated speech of youthful commander Raimundo Pachinuapa, crouching in dark glasses and fatigues under a crooked branch among waving grass, that spells out the event's historical significance:

What is the meaning of the Mueda massacre? What was the result of the blood spilt in Mueda, and of the blood spilt by many Mozambicans in many massacres that happened in our country? We can conclude that the blood that our people spilt in the many massacres that occurred in our country made them gain the consciousness that the only way to acquire national independence, of putting an end to humiliation and slavery in Mozambique, was the armed way. We can only fight Portuguese colonialism with weapons. After understanding this, the Mozambican people started to unite around a single organisation: they decided to form a front, the Front for the Liberation of Mozambique. And so there were no more problems, because the people were conscious that only by sacrificing the lives of our best sons we would be able to liberate Mozambique.5

The introductory address to a conference reflecting on 16 years of Mozambican historiography identified the Mueda massacre as one crucial event in need of reassessment. ${ }^{6}$ The oral testimonies that formed the basis of the official narrative, the authors argued, were delivered in relation to specific political agendas, especially the development of nationalism. The colonial documents were equally marked by 'distortions' concerning the regime's relation to emerging nationalism and the potential 'psychological destabilisation' the news might cause among Portuguese colonists. This situation of double bias was seen as productive rather than paralysing, requiring 'an effort to compare the various existing testimonies, on the side

\footnotetext{
${ }^{4}$ Waduvani went mostly by his nickname Shibiliti - 'matchstick' (Kibiriti in Kiswahili). The name Waduvani features also as Divani, Diwane, Divane. Following widespread usage, I will refer to him by his nickname. I use the spelling 'Vannomba', which reflects the Shimakonde pronunciation and meaning ('they marry him'), instead of the colonial misspelling 'Vanomba' (or 'Vanombe').

${ }^{5}$ Two Frelimo guerrillas appear in the film restored in 2012, referenced in the end credits as Cristino Maunda and Balthazar Nchulema. The first is, however, unmistakably Raimundo Pachinuapa, then governor of the Cabo Delgado province. According to Ruy Guerra, the other was an actor who, in a second cut of the film, recited the words that had been spoken impromptu by Pachinuapa in the first cut. This second cut was made at the insistence of Minister of Information Jorge Rebelo, against Guerra's will, to avoid the impression that the historical reading of the event was superimposed by Frelimo (Schefer, 'La Forme-Evénement', pp. 532-49). The version restored by INAC was a hybrid cut between the first and the second, in which Pachinuapa partly survived the censorship. The words translated here are spoken in the film by the actor. The peasants are referenced in the credits as Saide Namuolo and Muchanu Tumula, the native policeman as Ernesto Tchipakalia.

${ }^{6}$ T. Cruz e Silva and A. José, 'História e problematica das fontes', in A. José and P. Meneses (eds), Moçambique - 16 Anos de Historiográfia: Focos, Problemas, Metodologias, Desafios para a Década de 90, Vol 1. (Maputo, Cegraf, 1991), pp. 17-27.
} 
of the Portuguese and of the Mozambicans, reinterpreting the events according to the interests in play on both sides'.7

Two years later this challenge was taken up in a special issue of the journal Arquivo on the Cabo Delgado province; but only laterally, through a circumspect archival approach. The special issue presented part of the results of the research carried out in Mueda from 1979 to 1984 by the brigades of the History Workshops (Oficina da História) at the Centre for African Studies in Maputo. ${ }^{8}$ Two sets of documents were published: a collection of testimonies drawn from 1981-82 interviews with survivors, which included an emphatic account typed by an official informant; and the proceedings of the colonial process to Vannomba and Shibiliti. The former were subjected to deconstruction more than the latter. The eyewitness accounts were considered to have been influenced by 'official versions' and 'current political catechism', leading to the erasure of 'what would have been logical and natural: the emergence of a local movement grounded in ethnicity, defending the integration of the region in Tanzania [sic]'.9

Then the archives of the Portuguese secret police and intelligence services were opened. Based on a scrutiny of those sources and interviews with the Portuguese protagonists, historian Michel Cahen proposed a radical revision of the narrative in two short provisional pieces published without bibliographical apparatus, anticipating a longer work which is yet to appear. ${ }^{10}$ What kind of ingenious idea, Cahen asked, was it for a group of Makonde migrants to go and demand independence from the administrator of a remote northerly precinct, who by no means would be authorised to grant it? According to Cahen's reading of Portuguese intelligence, the Tanganyika-based delegations that had, in several waves, knocked at the door of the administrator of Mueda did not belong to MANU at all, but to two opposing associations: the Tanganyika Mozambique Makonde Association (TMMU), which was politicised and had close relationships with the Tanganyika African National Union (TANU); and the Mozambican African Association (MAA), which had more prudent objectives: facilitating the return of migrants from Tanganyika to Mozambique to live in better conditions. ${ }^{11}$ Vannomba and Shibiliti headed the latter, which they wanted to implant in Mueda under the name of Sociedade dos Africanos de Moçambique (SAM). The purpose of their meeting with the administrator would not be to demand independence but rather to negotiate a massive return of Mozambican migrants to Mueda; not against but with Portugal. For them uhuru wouldn't mean independence but 'freedom for the land' - essentially, a better life. The meeting degenerated when the crowds reacted negatively to the arrogant speech of the provincial governor, who ordered Vannomba and Shibiliti arrested and the native policemen to open fire on the people holding back the jeep carrying them away. Between 7 and 16 people died.

\footnotetext{
${ }^{7}$ Ibid., pp. 21-2.

${ }^{8}$ A list of the years of the brigades, and of their participants, is provided in Y. Adam, 'Mueda, 1917-1990: Resistência, Colonialismo, Libertação e Desenvolvimento', Arquivo: Boletim do Arquivo Histórico de Moçambique, 14 (1983), p. 83. For a critique, see C. Fernandes, 'History Writing and State Legitimisation in Postcolonial Mozambique: The Case of the History Workshop, 1980-1986', Kronos, 39, 1 (2013), pp. 131-58.

${ }^{9}$ Y. Adam and H.A. Dyuti (eds), 'Entrevista: Falam Testemunhas', Arquivo: Boletim do Arquivo Histórico de Moçambique, 14 (1983), p. 117.

${ }^{10}$ M. Cahen, 'The Mueda Case and Makonde Political Ethnicity: Some Notes from a Work in Progress', Africana Studia, 2 (1999), pp. 29-46, and 'Os heróis de Mueda', Agora: Economia, Política e Sociedade, 2 (2000), pp. 30-31.

${ }^{11}$ I simplify Cahen's reconstruction here, which identifies other competing groups, such as the TMMA and the Zanzibar Maconde and Macua Union (ZMMU). TMMU would then become MANU.
} 
This retelling stripped 16 June of all its mythical meaning - not a bold demand for independence by visionary leaders but a meek plea for cohabitation with the Portuguese under better conditions, not a popular protest but a meeting gone awry, not a massacre but a riot, not an event but an accident - while paradoxically reiterating two central tenets of Frelimo's teleology: that it had been an ethnic moment in a progression toward full nationalist consciousness, and the trigger of the armed liberation struggle. Anointed by the aura of an undisclosed archive, Cahen's version took upon itself the burden of history, putting into question even Chipande's presence on the day through a dubious syllogism. ${ }^{12}$

After the turn of the millennium, the historical public sphere opened up significantly both in Mozambique and in Portugal: here, through a multiplication of voices enabled by political pluralism; there, through a belated reckoning with the colonial past. ${ }^{13}$ This did not enable the emergence of a new narrative of the Mueda massacre. On the occasion of the massacre's 5oth anniversary, the Mozambican Arquivo do Património Cultural promoted the publication of various pamphlets which regurgitated the official narrative to the point of parody. ${ }^{14}$ The groundbreaking 42-episode documentary A Guerra, produced by Portuguese television, featured an extensive coverage of the Mueda events, including testimonies by Chipande, Pachinuapa and aspirante (officer designate) Manuel Godinho. The montage of opposing versions opened a chasm as deep as the legendary ravine in which the demonstrators, fleeing from Portuguese

machine-gun fire, would have tumbled to their deaths. Here the old stories retold by leaders no longer youthful, there the post chief's unabashed admission of having killed a man who'd attempted to stab the Governor - 'I was left in front of the negro and the negro comes down with the knife and tears my jacket and I shoot him down'. ${ }^{15}$

How does one emerge from such an impasse? The obvious solution is a return to the archives that enabled the opposite versions to emerge: the written archive of Portuguese intelligence, established in the heat of the events; and the ever-growing oral archive of Mozambican testimony. The contrastive reading opened up by Adam and promised by Cahen is yet to be carried out. ${ }^{16}$ Unless one surrenders to the idea of a total indeterminacy of history, the task is worth pursuing.

\footnotetext{
12 The dubious syllogism goes as follows: (1) Chipande was a member of the Liguilanilu cotton co-operatives; (2) the co-operatives were not related to TMMU or MAA/SAM (which is itself questionable); (3) Chipande might have not been in Mueda.

${ }^{13}$ See, respectively, two articles in Revista Crítica de Ciências Sociais, 106 (2015): J.P. Borges Coelho, 'Abrir a Fabula: Questões da política do passado em Moçambique', pp. 153-66, and B. Sena Martins, 'Violência colonial e testemunho: Para uma memória pósabissal', pp. 105-26.

${ }^{14}$ C. Tiane and A. António, Massacre de Mueda: Climax da Consciência Nacionalista (Maputo, ARPAC, 2010), which refers to 'thousands of Mozambicans [...] barbarously murdered', pp. 4-5; E.J. Mpalume, Massacre de Mueda: Símbolo da Resistência Moçambicana (Pemba, ARPAC, 2010); and Massacre de Mueda: 50 Anos Depois (Pemba, Sotil, 2010). Mpalume worked as guide for Cahen during his short field trip to Mueda; he privately holds sceptical views about the official narrative.

15 J. Furtado, A Guerra. Episodio 6: Pidjiguiti e Mueda (Lisbon, Rádio e Televisão de Portugal [RTP], 2007). In obeisance to conservative archival politics, RTP and Furtado denied me access to the series' raw filmed material. This is a symptom of Portugal's impasse in dealing with its colonial past. The name of the old man killed by Godinho, Mueda's first victim, was Daudo Kanjugwili, from Matambalale.

${ }^{16}$ A promising gesture in this direction is L. Dias Laranjeira, 'Mashinamu na Uhuru: conexões entre a produção de arte Makonde e a história política de Moçambique’ (PhD thesis, Universidade de São Paulo, 2016), pp. 137-83.
} 
Yet some kind of reorientation is needed before the archival dip. For if the two archives speak divergent languages, they are also united by a secret solidarity: an overemphasis on leaders and organisations. Colonial intelligence tracks individuals, associations and political programmes with the objective of controlling them; nationalist testimony casts them as visionary and pioneering. Both consider the rural masses as a passive medium, target, susceptible to being excited only when the right reagent is poured. The shared assumption is a modernist urban vanguardism. ${ }^{17}$

Mueda exceeds such confining terms. What made thousands of people march to the whitewashed administration building on top of the hill that is today known as Maimyo ('history', in Shimakonde) to partake in a meeting between migrant labourers barely known to them and the colonial governor? What were their expectations? What inflamed their imaginations? What dream did they heed? What history did they think they were making? Quibbling over organisations and demands without addressing these fundamental questions is like painting a leaf in lieu of the forest. How does one tap into such deep strata?

In East Africa song is - and has been for centuries - the idiom that bridges feeling, politics and the imagination. Songs induct children into adulthood, ${ }^{18}$ shape places and persons through competitive play, ${ }^{19}$ channel political mobilisation and organisation; ${ }^{20}$ they are the fibre from which nations are woven, ${ }^{21}$ memory machines, ${ }^{22}$ the voice of the voiceless. ${ }^{23}$ The exuberance of new genres such as hip-hop is a reflection of music's deep, long-standing social embeddedness in the region. ${ }^{24}$ It is the thread you trace to reveal the entire fabric of social life.

As a preliminary ground-clearing gesture, this essay follows the tracks of a number of songs whose sound surrounds the events of 16 June. Some of them are well-known popular tunes; others were part of the theatre piece filmed by Guerra; others still I have recorded and perhaps saved from oblivion. Taken together, they constitute an alternative archive, not necessarily spontaneous but differently inflected. ${ }^{25}$ The endeavour is experimental: to let the songs ring and to heed their echoes and reverberations across other sources and accounts, so as to achieve a rereading and a rearranging of the 'evidence'. The aim is to

\footnotetext{
${ }^{17}$ For a critique, see D. Chakrabarty, Habitations of Modernity: Essays in the Wake of Subaltern Studies (Chicago, University of Chicago Press, 2002).

${ }^{18}$ C. Kratz, Affecting Performance: Meaning, Movement and Experience in Okiek Women's Initiation (Washington, Smithsonian Institution Press, 1994).

${ }^{19}$ F. Gunderson and G. Barz (eds), Mashindano! Competitive Music Performance in East Africa (Dar Es Salaam, Mkuki Na Nyota, 2005); P. Israel, In Step With the Times: Mapiko Masquerades of Mozambique (Athens, Ohio University Press, 2014).

${ }^{20}$ S. Geiger, TANU Women: Gender and Culture in the Making of Tanganyikan Nationalism (London, Heinemann, 1997).

${ }^{21}$ K. Askew, Performing the Nation: Swahili Music and Cultural Politics in Tanzania (Chicago, University of Chicago Press, 2002).

${ }^{22}$ R. Gearhart, 'Ngoma Memories: A History of Competitive Music and Dance Performance on the Kenya Coast', (PhD thesis, University of Florida, 1998).

${ }^{23}$ L. Vail and L. White, Power and the Praise Poem: Southern African Voices in History (Charlottesville, University of Virginia Press, 1991); L. Fair, Pastimes and Politics: Culture, Community and Identity in Post-Abolition Zanzibar (Athens, Ohio University Press, 2001).

${ }^{24}$ K. Njogu and H. Maupeu, Songs and Politics in Eastern Africa (Dar Es Salaam, Mkuki Na Nyota, 2007).

${ }^{25}$ For a theorising of music (or sound) as archive, see A. Hoffman, 'Introduction: Listening to Sound Archives', Social Dynamic, 41, 1 (2015), pp. 73-83.
} 
produce a more expansive history, which ventures in the territory of emotion, imagination and utopia - that space of 'chilling precision' where 'your mind jumps ahead'. ${ }^{26}$ The writing itself follows the unfolding of songs, in reverse chronological order and then back again towards the present.

The assumption that music might be a medium more likely to 'brush history against the grain' might take you off guard. ${ }^{27}$ Consider Mpambe, the most defiant meteor in the bustling new scene of Shimakonde hip-hop. As this young artist's hope of becoming a professional musician faded in the face of the digitalisation of media and conscription into the military, his language evolved towards an imagery of blood, death and despair; his sound became darker and thicker, his accents angrier. Yet the notes of the one composition devoted to the history of the Mueda massacre, produced under elections, are all too familiar:

Nandele kaka Mpambe

Vadyoko apa vandida pakulota wako uvamanyie

Frelimo mwaitunduvangidile

Napashi paitupandukangidile

Pumula bai ndivaupe ndyoko!

Wakwanalela Shibiliti

Lwengo lwo ku-Moshambiki

Lwotupatidi unaiti

Nakune tuja maiti

[...]

Akatwala shipinga shake Vannomba namu Namiva

Pamo vakamboka Luma

Ndawika ku Moshambiki

Mwenentete akapata kwona

Vakapisha mikutano

Makaja uti mwapitile

Navakaunganila limu uti vakadyane kuwiboma

Muitalee kumi na sita mwedi asita pamwaka nasitini

Njungu akapata kumanya nyani mwene Moshambiki

Mwenentete ajugwa unaiti
Salutations big brother Mpambe

These children have come so that you can teach them

How Frelimo began

And where did it bring us

Chill and I'll give it to them, kid!

Shibiliti was the foreseer

Of the path to Mozambique

Of how we would get Unity

And here we come back corpses

He took his own group, Vannomba and Namiva

Together they crossed the Rovuma

To arrive in Mozambique

The people saw them

They set up meetings

In all hamlets where they passed

And they all agreed on one thing: to meet at the district

On the date of the sixteenth of the sixth month, 1960

So the white man gets to know who owns

Mozambique

The people asked for Unity

\footnotetext{
${ }^{26}$ B. Dylan, Chronicles (New York, Simon and Schuster, 2005), p. 52.

${ }^{27}$ W. Benjamin, Illuminations (New York, Schocken, 2007), p. 257. I am less interested here in the disciplinary rendering of Benjamin's formulation as 'reading against the grain' than I am in his call to redemption (Rettung) of the past.
} 
Kwa itangodi lidonji

Mwana akanatenda kuva nae nantenda

Kuvabyanga vene shilambo vashivakanyo' matola

Na mutata makon'go

Ling'oto paing' ano yakwita

Kutwaligwa Shibiliti

Nammuki' nankaja Polito Amelia

Pwiti likola kupeta

Akashiva nanae gweka wadimongo dyakupindikula

Shibiliti vandintwala pashikapali

Navammupa shaushanga

Kubakila shilambo valya

Frelimo oye

Chissano oye

Samora oye

$\mathrm{Na}$ Mondlane baba namu baba Shibiliti

Vandinjila Moshambiki yatupatidi unaiti

Wetu tuvana' shalumo

Likola limo

Tutende unapamo
With a mouthful of a speech

An innocent child was made into culprit

They killed the owners of the land, whom they used to flog

And the father signed off

Then because of refusing

Shibiliti was taken

And brought to the house of Porto Amélia

The Portuguese wiped out the family

To be the only one with the strength of overturning

They took Shibiliti with no right

And made him suffer

To be left eating the country

Viva Frelimo

Viva Chissano

Viva Samora

And baba Mondlane and baba Shibiliti

Entered into Mozambique so that we could have Unity

And be together

One family

To live in unity ${ }^{28}$

The history of the massacre occupies the first one-and-a-half minutes of a long piece dedicated to the genesis of Frelimo. The framing is indeed familiar: the story is told in the teleological mode whereby the massacre inevitably leads to the rise of the party, and Shibiliti is inserted in the official litany of leaders side by side with Mondlane. But through evocative language the song also presents some striking dissonances. The first is the floating sentence 'we come back as corpses', in which the word maiti ('corpse') is rhymed with unaiti ('unity', 'independence'). Is this an oblique statement on the trajectory of the dream of unity? Or does it evoke the late reburial of Shibiliti from the province of Inhambane, where he was left to languish unacknowledged? The second dissonance is the mention of Verónica Namiva - one of the Makonde 'traitors' processed at the 1975 Nachingweia trial as part of Shibiliti's group in his last journey. The figure of a woman alongside the two appears as a lapse in the most official of testimonies, and Namiva has been placed at the scene by other eyewitnesses. ${ }^{29}$ At the very least, Mpambe's inscription of an archetypal counter-revolutionary at the heart of the event signals that the song's origins lay partly in oral tradition.

\footnotetext{
${ }^{28}$ Mpambe, 'Frelimo Oye' (Pemba, One Dollar Production, digital single). Since the MP3 has replaced the audio cassette as support (around 2010), local music is produced and circulated in digital form. Artists do not get any revenue from their work.

${ }^{29}$ João Cornelio Mandanda locates Modesta Neva at the scene on 16 June. This is, however, impossible, because Neva was arrested on 27 April, as part of the SAM 'group of seven' led by Simon Nshusha, and died in jail in unknown circumstances. Similarly, Pachinuapa refers to a (non-existent) Verónica Neva in Moçambique: 40 Anos de Independência e Soberania (Maputo, Nachingwea, 2015), p. 36. Two eyewitnesses recall Verónica Namiva as being present on the day: Cericada Namawa, interviewed by Yussuf Adam, Ntushi, 1981; Gabriel Elias Shitandala, interviewed by Paolo Israel, Mwambula, 11 June 2015. In a document mentioned in A. Zengazenga, Memórias de um rebelde: Uma vida pela Independencia e Democrácia em Moçambique (Amazon, Creatspace, 2013), Namiva features as one of the founders of SAM alongside Shibiliti and Vannomba.
} 
Dance ensembles have more concise renderings. The choir of the war veterans' mapiko masquerading group from the town of Mueda eschews all historical detail to paint with a few strokes a mournful affective tone:

Wetu pamaimyo

Wakati watushamananga

Mwedi wasita

Italee kumi nasita

Atunapuwa shinu

Tuvalilile

Vavetu vanshambelo voe

Vajaite shingumi

Ing'ondo yapa-Mweda po

Atunapuwa shinu
Us, here at history

When they call us

On the sixth month

On the sixteenth

We don't rejoice at all

We cry for

Our friends, the many heroes

Who lost their lives

In the war of Mueda, here

We don't rejoice at all ${ }^{30}$

The texture is pervaded by officialdom: history, fallen heroes, iconic dates, and the massacre cast as a war. ${ }^{1}$ Yet the song also responds to a call to history coming from above ('they') with a refusal to be joyful and to celebrate the event retrospectively for the effects it had. It was precisely on that call to revolutionary sublation that Chipande's account closed: 'the 16th of June ceased to be a day when the dead of Mueda are mourned to become instead a day when opposition and fight without truce against the system that killed them is reaffirmed'. ${ }^{2}$ The song affirms instead unresolved grief. The melody is darker and gloomier than the upbeat choruses typical of this genre of mapiko and ends on the long monotone - 'We don't rejoice at all'.

The correlation between death and the nation is directly and simply established in the most renowned popular song referring to Mueda as a site of history, a song which transcends genre and occasion:

Tuke tuke

Tuke manemba tuke kumaimyo

Tuke tuke tuke tu

Tundakadyana ku-Mweda

Ku-Mweda kunyamani?

Palikabuli lyashilambo
Let's go, let's go

Let's go boys, to history

Let's go, let's go

Let's meet in Mueda

In Mueda, what's there?

At the graveyard of the nation

The tune is upbeat, almost joyful, as it calls young men to an allegorical meeting at the graveyard on top of the hill where the ancient colonial administration sits, commonly known

\footnotetext{
${ }^{30}$ Mapiko choir, Nihere group, Mueda sede, recorded 16 June 2003. The song was still sung in 2015 by this and other groups.

${ }^{31}$ I analyse the incorporation of party watchwords and national symbols into mapiko and Makonde singing more generally in Israel, In Step With the Times, pp. 143-206.

${ }^{32}$ Chipande, '16 June 1960-1970', p. 14.
} 
as maimyo - 'history'.33 One should, however, exercise some caution in translating shilambo simply as 'nation'. While the word is indeed used catachrestically to render the Portuguese nação, in origin it defines the land under the authority of a lineage leader of a segmentary political organisation, the 'elder owner of the land' (nang'olo mwene shilambo), and therefore in essence shifting and non-territorial.34 The word still carries that original ambiguity; in the song it can be read as referring to the nation, or to some undefined commons centred on Mueda.

A traitor thrown on the stage of history, unresolved mourning instead of teleological joy, deterritorial echoes within the idea of nation: a few small dissonances agitate the otherwise quiet sound of officialdom coming from contemporary Mueda.

The only known rendition in song of the Mueda events as experienced by an eyewitness was composed by Bernardino Namba Juakali and performed from the second half of 1960 onwards. Juakali was then the song-master of the foremost mapiko group in the area then known as Muidumbe, the Makonde plateau's south-eastern lowlands. In the transitional moment of the 1950 os a new song genre had been added to the ever-evolving repertoire associated with mapiko masquerading: winding, elaborated poems in recitativo descending melody, embroidered with words in Kiswahili - the language of labour migration - and often closed off with the artist's name, inscribed as a signature. These song-poems were called vilanga (singular, shilanga), from the name of an older form of poetic storytelling. Juakali was among the handful of renowned vilanga performers who would meet for competitive exchanges at initiation rituals or festivities. 35

When on 14 June 1960 native authorities made the rounds of the hamlets to announce the great meeting to come, Juakali heeded the call. He walked to the nearby Nguri lake and cut a branch from the softwood tree growing on its shores, which went by the name of uhuru, bent it like a small cane, wore it around his elbow and scrambled up the great climb to Mueda.

And this was his song:

\footnotetext{
${ }^{33}$ From kwimya, 'to narrate', 'to bring past events into memory'. The word in Shimakonde is a plurale tantum: there is no history, always histories. See Israel, In Step With the Times, p. 156.

${ }^{34}$ On the 'elder owner of the land', see H. West, Kupilikula: Governance and the Invisible Realm in Mozambique (Chicago, University of Chicago Press, 2005), p. 31.

${ }^{35}$ On shilanga, see Israel, In Step With the Times, pp. 128-9, 132-6; and C.D. Ngundangu, 'Género e Funções da Poesia Oral Makonde' (Licenciatura dissertation, Universidade Eduardo Mondlane, 2002).
} 
Ibalugwa kwaloka ku-Mweda

Shibiliti walota kuwika

Amekuja mwenyewe Shibiliti

Pamoja Faustino Vannomba

Nkutano aramishi ku-Mweda

Manemba shamananga tuke tukaigwilile

Mpurtukeshi mbaya-mbaya

Nae akashindwa shaliya

Mportugeshi wananga dyoni

Shibiliti mmunge

Faustino mmunge

Vandilinga kummunga Shibiliti kunshindwa

Vandilinga kummunga Faustino kunshindwa

Upingo kulumuka

Vamakonde anditangola nakupwatekanga

Shibiliti apakiligwa aenda kushinu

Mwindi Nshina mbaya

Lijanga andijela

Vamakonde vandyatika

Governadoli andinjila mulukoma

Bashitola kutwala

Alamulila ing'ondo, omba

Piga wé Vamakonde vabyae

Omba wé Vamakonde kutwangaisha

Yuti kupiga

Likola lindyalibika
A letter coming from Mueda

Shibiliti is coming

Shibiliti is coming in person

Together with Faustino Vannomba

There is a meeting on Thursday in Mueda

Boys, they call us: go and listen

The Portuguese are bad, bad

They don't know any law

They are shameful

Tie up Shibiliti

Tie up Faustino

They tried to tie up Shibiliti, they failed

They tried to tie up Faustino, they failed

The handcuffs broke

The Makonde spoke full of pain

Shibiliti won't be taken, he won't go anywhere

The Indian China is bad

He threw a stone

The Makonde responded

The governor took shelter on the veranda

He drew a gun

He ordered a war, shoot

Shoot, go, kill the Makonde

Shoot, go, the Makonde are annoying us

Guns were fired

The family was ruined ${ }^{36}$

The shilanga presents the events as many experienced them: the news of the arrival in person of the famed Shibiliti; the convocation to the assembly; the Portuguese arrogance ('bad', 'shameful', 'lawless'); the popular anger at the arrest of the two leaders; the order to shoot. Two details are, however, added to the story. The first is the throwing of the first stone by the Indian shop-owner known as China, which implies that the crowds responded to a provocation rather than initiating the disorders. 37 The second is the mysterious incident of the handcuffs, which would have broken as they were fastened first on Shibiliti and then on Vannomba when they were about to be ushered into the jeep to be carried away. Juakali swears that he saw the handcuffs fall apart thrice before the policemen resolved to just push the two into the car. The detail is confirmed by several eyewitnesses. ${ }^{8} \mathrm{~A}$ real occurrence might have been amplified to mythical proportions: the handcuffs that refuse to obey the colonial master, the promise of future freedom.

\footnotetext{
${ }^{36}$ Bernardino Namba Juakali, recording, Ruarua 5 August 2008.

${ }^{37}$ This detail finds also confirmation in Vannomba's interview with Harry West, 'Sorcery of Construction and Sorcery of Ruin: Power and Ambivalence on the Mueda Plateau, Mozambique (1882-1994)' (PhD thesis, University of Wisconsin, 1997), pp. 147-9; and West, Kupilikula, pp. 136, 156. Casa China is the oldest shop in Mueda; its owner, Assamu Sulemane Juma, was despised by Mueda residents for his cruelty.

${ }^{38}$ See, among others, Januário Joana Makai, interviewed by Paolo Israel, Mueda, 20 March 2005 and Akissa Victor Nauka, Augusta Namwalu, Constancio Nyoka, Januário Joana Makai, Lourenço Afonso Nikutwale and Ncalewa Bwaluca, interviewed by ARPAC team, Mueda, 2 June 2010.
} 
A missing term connecting the two incidents can be found in a letter of a Makonde witness intercepted by the Mueda post chief:

the Governor took them inside and handcuffed them. Then they came here, outside, [which] was when the people asked to the Governor, these go arrested. Did they commit any crime? This question was posed 3 times [and] since the Governor did not respond a group of Makonde grabbed the car that was going away, they were un-handcuffed and the monhé China threw a stone and the maconde threw stones at the whites and the whites shot in the air after they started shooting at our people, they killed us 100 people and many wounded. 39

The eyewitness account does away with magic, but the handcuffs' unfastening still hinges around the allegorical number three - the times the question asked to the Governor goes unanswered: did they commit any crime? China's stone then breaks the impasse and sets off the catastrophe.

But Juakali's song doesn't conclude on death or defeat. It moves into the future:

Tumpige shimu aende Maputo mpaka Pemba Let's make a phone call, to Maputo until Pemba

Majibu analoka shinu

Majibu aloka Tanzania

Monjane akaigwa ing'ondo andikubali

Bwana Monjani kuma kutangola

Mungulinde kwanja

Ngwende ku-laya Portuguesi

Nikavaudye ing'ondo vakalota mwiu vangwaulile

Bwana Mondlane kutango' shana

Ngulinda nangu kwanja

Monjane kupita andikodyana namu Shibiliti akó

Faustino, Tiago

Vajungu Portuguesi vankwangaika

Portuguesi kutila ulaja kuleka gweka

Vanyopa Mondlane

Mana Mondlane alota ing'ondo pamo

Nangu ing'ondo yó angumanya

Ngwenda kwetu akó ngwikala

Portuguesi kutukuta Moshambiki kuleka shana

Vajopa ing'ondo

Mondlane alota ing'ondo

Nangu ing'ondo yó angumanya

Ngwenda kwetu akó ngwikala
There is no answer

The answer comes from Tanzania

Mondlane, as he hears about the war he agrees

Mister Mondlane came out and said:

Wait for me first

I will go overseas to the Portuguese

To ask them: if they want a war they must tell me

Mister Mondlane spoke well

Wait for me first

Mondlane went and met Shibiliti there

Faustino, Tiago

The white Portuguese are all worried

The Portuguese flee overseas, they leave us alone

They fear Mondlane

Because Mondlane wants a war together

I don't know anything about this war

Let me go back home and sit down

The Portuguese flee and leave Mozambique in peace

They fear a war

Mondlane wants a war

I don't know anything about this war

Let me go home and sit down

This version of the shilanga was sung by Juakali to me in 2008, and in the early years of the

${ }^{39}$ Gaspar Kumagwelu to Jonas Simão, 10 July 1960, Torre do Tombo archives, SCCIM, L/10/4/CD, 3/657. 
liberation war, according to his recollection. $4^{\circ}$ It puts on the scene Eduardo Mondlane Frelimo's first president - together with Vannomba, Shibiliti and Tiago Mulla, who had visited Mueda on 22 March 1960 as leader of the TMMU and was arrested as a consequence. ${ }^{41}$ This phantasmagoria seems to refer to the historical conjuncture in which Mondlane began to threaten the Portuguese with the possibility of the guerrilla war. Yet this was not the version Juakali sang in the aftermath of the events at a great mapiko gathering in the house of Naengo, which got him arrested for subversive speech and carried to Porto Amélia for interrogation. $4^{2}$

What is left of the original version is only a summary report from an eavesdropping native policeman:

Faustino came and the White put him in Tanganyika. He then came back accompanied by Quebrite and the White were all worried. They were afraid and without notice made war. The Black escaped and the White took Faustino and Quibrite to Lourenço Marques. Nyerere went there to attend the matter, returned now to Tanganyika and went now to America. They only wait for Faustino and Quebrite to fight and force the White to escape and go away. Nyerere is the Son of God and when he wants no-one can defeat him. 43

One can safely assume that the name of Nyerere was replaced by Mondlane's later on, as a homage to the new leader - something quite common in Makonde singing. Restoring the figure of Nyerere and backdating the song by two years, a different picture emerges. War is only a vague possibility. All hope is put in Nyerere's godly power to scare off the Portuguese and chase them back to their own land. Of war, Juakali wants to know nothing. As individual as it may be, the sentiment is far removed from the teleological narrative that wants the Mueda massacre to be the point of collective awakening to the inevitability of the armed struggle. The singer has but one desire: to go home and sit down.

*

In the popular play filmed in Mueda, Memória e Massacre the crowds gathering in front of the Mueda administration enter the scene singing:

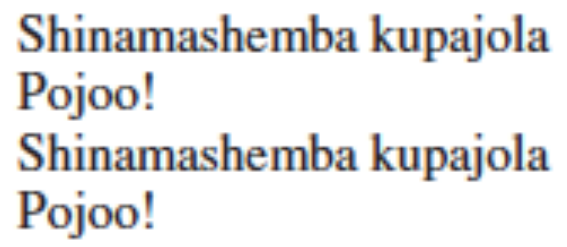

The way of the Mashemba, to assault Assault! Like angry invaders, to destroy Demolish! ${ }^{44}$

\footnotetext{
${ }^{40}$ I could not interview Juakali again after our first meeting in 2008: when I went back to Shitunda in September 2014 he had just passed away, stung by a swarm of bees as he walked back to the fields to look for an ID that had slipped out of his bag.

${ }^{41}$ In the popular theatre, he is conflated with the delegation led by Simon Nshusha. A colourful rendition of his visit is provided in R. Pachinuapa and M. Manguedye, Vida do Casal Pachinuapa (Maputo, JV Editores, 2009), pp. 27-8. Cahen also muddles the two delegations, erroneously asserting that Tiago led another group of seven, whereas he came alone; see 'The Mueda Case', p. 39.

42 Porto Amélia was called Pemba by the Makonde before this was chosen as the new name for the city in the post-independence period.

${ }^{43}$ TT, Ferraz Freitas, Correspondencia recebida, 1 de Março 1961, SCCIM, L/10/4/CD, 3/563-4.

${ }^{44}$ This and the following song feature also in the transcription of the theatre piece in Mpalume, Massacre de Mueda, p. 97.
} 
The tune is repeated at rising pitches several times until it rests on the ideophonic pojoo! Then another song is taken up; brisk, almost military:

\section{Nakashenga \\ Nakashenga kuuluka mwandege Nakashenga}
Akapadi' njungu waku-Mweda
Kunneka Nyerere watawala
E-e-e

\section{The black kite \\ The black kite flies as a plane The black kite}

\author{
May the white of Mueda die \\ And leave Nyerere to rule \\ E-e-e
}

To an ear trained in detecting the stylistic stratifications of Makonde music, the manner of these songs belongs squarely to the late colonial period. Their metaphorical density is also in stark contrast to the political platitudes that characterise the post-independence period. Were they perhaps sung at the time of the massacre? Or do they represent something like a popular memory of the event?

The first song left some traces in the archive established by the History Workshop brigades in the 1980s. One Catholic priest based at the Imbuho mission, Padre Elias, mentioned kupadiola as a widespread women's song, which he interpreted as meaning 'to push down and destroy'. 45 The priest heard it sung at the collective production co-operatives established by Lázaro Nkavandame in the lowlands of Imbuho in the aftermath of the massacre. 46 He did not know whether the song 'was a movement as such, or just the expression of a nationalist sentiment'. Kupajola reappears in an interview with Cornélio João Mandanda, who refers to it as a 'war song' that he heard in the co-operatives between 1963 and 1964.47 Most Makonde persons of the right age heard it in the years preceding the beginning of the armed struggle; it has been transmitted to new generations. 48

The song itself is only apparently simple. The first word, shinamashemba, refers to the name of a Makonde lineage, the Vanamashemba, hailing from the northern lowlands of kundonde and possibly related to the Makwe people living along the Rovuma river.49 According to

\footnotetext{
${ }^{45}$ Interview with Padre Elias, Padre Pedro and Padre Teodoro, 11 August 1981, conducted by Yusuf Adam, Colin Darch and Anna Maria Gentili. At the priests' request, the interview was not recorded. I base my reconstruction on Darch's notes (Colin Darch personal archive, Cabo Delgado Notes box). For a discussion of the history of the Catholic missions in Mueda, see West, Kupilikula, pp. 109-32.

${ }^{46}$ Lázaro Nkavandame first established cotton co-operatives (SAAVM, also known as ligwilanilu - 'mutual understanding') in 1957, which worked as centres of political mobilisation. These were shut down after the massacre. New rice production co-operatives, called Cooperativa de 25, were initiated in 1960-61 in Mueda and Imbuho. See A.M. Gentili and Y. Adam, 'O movimento Liguilanilu no Planalto de Mueda, 1957-62', Estudos Moçambicanos, 4 (1983), pp. 41-75.

${ }^{47}$ Interview with João Cornélio Mandanda, 18 August 1981, Arquivo Histórico de Moçambique (hereafter AHM), oral history section. Mandanda was a protagonist of the co-operatives and is the informant who provided the long, typed account of his participation in the Mueda massacre printed in Adam and Dyuti, 'Entrevistas', pp. 122-6.

${ }^{48}$ For instance, Estevão Mpalume heard it in the years of his boyhood: the late 1950s or early 1960s. I was surprised to find out that a young Makonde medical student who came to speak to me after my presentation to the conference 'Arquivos e Investigação Científica', held in Maputo, 18 August 2015, on the 80th Anniversary of the AHM, also knew the song. He responded to my surprise with contempt: Sha! Ngutikinange shakwetu? 'Duh! Would I ignore the home stuff?'

49 The origin of the Vanamashemba in the northern lowlands is widespread knowledge. According to Davety Mpiuka, there are many Vanamashemba in the area of today's Diaca. Their relation to Makwe people was postulated by Manupa Kanyaga Matakenya and
} 
Estevão Mpalume, this lineage was known in pre-colonial times for its aggressive invasions of neighbouring settlements; the locution shinamashemba, 'the way of the Mashemba people', was therefore used as a coded metaphor to indicate something like 'a group who gets worked up to invade', a 'raging invasion', or more broadly 'a spirit of rage'..$^{0}$ The reference to the precolonial history of a lineage evokes a resistant subject without reference to any organisation, person or place: as raw rage resurgent from the past. The verb kupajola means 'to assault' or 'to demolish', and pojoo is the ideophone from which the verb derives, a sound evoking a sudden strike or destructive blow. The juxtaposition generates an impersonal, incremental effect, underlined by the repetition and the progressive rise in pitch.

According to several eyewitnesses kupajola was sung on the day of the massacre. It served as a marching anthem for people coming from the northern areas of the plateau (today's Nangade). ${ }^{51}$ Some heard it sung by sections of the crowds during the long wait for the Governor under the driving rain in front of the administration. ${ }^{52}$ It then remained associated with the event, almost as its affective soundtrack.

The second song seems instead to have been composed in the event's aftermath, as reaction or commentary.53 It also left a trace in the priest's memory, who mentioned 'songs about Nyerere - he had a mythical status at this time on the Planalto [plateau]', the period being left vague.54 Miguel Patime, administrator of Mueda in 1990, affirmed that 'after these events [of Mueda] the people began to compose and sing songs about the leaders of African countries'.55 The very mention of Nyerere implies that the song was composed before 1962: as shown by Juakali's shilanga and by a long tradition of Makonde praise singing, new names of leaders are immediately incorporated into the texture of old compositions.

The song entwines a very explicit death wish with an obscure metaphor. Nakashenga, the black kite (Milvus migrans), is a widespread bird of prey. Why does it 'fly like a plane'? Multiple, divergent readings are possible. The song might establish a connection between colonial rapacity and the technology of air flight; or it could imply that the predator must fly away like a plane - leave, go. But could the predator be Nyerere himself, coming to snatch away the country? Or could the image of the busy nakashenga be an oblique memory of the storms of birds of prey which according to local lore descended on the likabakobo ravine to feast on the bodies of those who had fallen there to their doom, escaping colonial fire? What is spelled out very clearly is the wish for the colonial master to die, to be replaced by Nyerere.

Madebe Robath to Atanásio Nyusi, e-mail communication, 3 April 2016. Makwe people constituted the bulk of the battalion that subdued Makonde resistance in the Namakande battle of 1917.

${ }^{50}$ E.J. Mpalume, personal communication, 3 August 2015 and 31 March 2016. One of the women who sang the song in the 2015 play also translated shinamashemba as 'an angry people' or 'destroying people'. A Makonde war veteran in Maputo offered an imaginative translation inspired by liberation struggle language, as Guerrilha e espirito de avanço seguro, 'Guerrilla and spirit of firm advance' (handwritten note, 17 September 2015).

${ }^{51}$ Frank Ntaluma, personal communication, Lisbon, 30 July 2016, from notes taken at an interview with his father, Kaniki Ntaluma, Nanyagaia, September 1990.

52 Paulo Shangolipinda, interviewed by Paolo Israel, Mwambula, 30 September 2014; Enrique Cosme, interviewed by Fidel Mbalale, Matambalale, 30 September 2014.

${ }^{53}$ This was the opinion of the old women who sang the song in the theatre group, as well as of two old singers in the village of Matambalale, related to Shibiliti.

${ }^{54}$ Padre Elia, Pedro and Tobia, interviewed by Colin Darch, Jacques Depelchin and Anna Maria Gentili, Pemba, Cabo Delgado notes.

${ }^{55}$ E.J. Mpalume, 'Shitunduvangilo sha makumbukilo a uniaiti wa shilambo' Lyalosho, 3 (Maputo, Tempográfica, 1990), p. 12. 
Tucked in the closing titles of Mueda, Memória and Massacre is a third song which according to Licinio de Azevedo - who carried out background research on the play - was sung on the day. $5^{6}$ The song is indeed unequivocally cast in the present:

\section{Nelo shambone shambone Shambone tumanyika}

\section{Today something good, good Let us know something good}

A hope too big for words is woven into these two lines, with the melodic repetition of the word shambone, good. Something will be communicated, informed, coming out of the meeting. Let it be what we want. In contrast with the previous songs, this one was generally forgotten and is no longer performed in the play - perhaps because the hope was betrayed too sorely, only rage and death being left to be voiced.

The man who carried Vannomba on his bicycle at the head of the procession leading from his native hamlet of kuna-Nandang'a to Mueda on 16 June 1960 heard yet another song intoned on the day. It went like this:

\section{Nandonda \\ Nandonda mwene shake Tundapata tuvene}

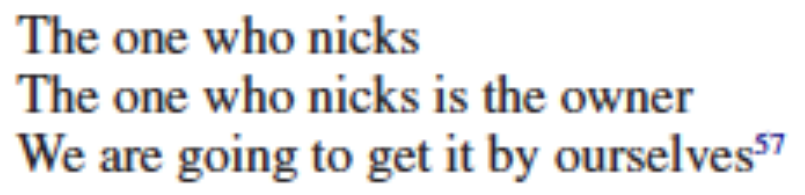

57

'The one who nicks [or chips] is the owner' is a Shimakonde proverb employed to resolve ownership contestations. $5^{8}$ When used in relation to hunting, it implies that the one whose arrow wounds a prey first has the right to the entire animal, even if others hit it subsequently. When it comes to eating, it means that a plate of food belongs to the one who first bit into it; or a glass of drink to the one who took the first sip. For those who could understand it, the song would mean: 'As long as you might have stayed, the one who arrived there first is the owner of his own thing'.59 The thing in question was shilambo, the country. The second verse expressed - not proverbially but literally - the determination to go and get it: 'we', the owners.

Four songs: a cry of destructive rage, a death wish entwined with a metaphor of predation, an inexpressible hope, a statement of ownership. Despite the uncertainty concerning their origins, none of them belongs to the history of nationalism as defined by Frelimo - what João

\footnotetext{
${ }^{56}$ L. de Azevedo, 'Há qualquer coisa perigosa em Mueda', Tempo, 436 (1979), pp. 20-22. Azevedo refers to three songs being sung in the play: one invoking Tanzanian independence, another saying 'today we have something', and the third saying 'there is something dangerous today'. The latter must refer to kupajola.

${ }_{57}^{57}$ Enrique Paulo Cosme, interviewed by Fidel Mbalale, 30 September 2014.

${ }^{58}$ On the concept of ownership in Shimakonde, see Israel, In Step With the Times, p. 84.

${ }^{59}$ Enrique Paulo Cosme, interviewed by Fidel Mbalale, 30 September 2014.
} 
Paulo Borges Coelho termed 'the liberation script'. ${ }^{60}$ They crystallise a set of feelings and aspirations which pertain to the transitional phase of the late 1950s and early 1960s; in the case of the first one, more particularly to women. They also reveal a subterranean connection between the Tanganyikan migrants and Nkavandame's cotton co-operatives, in spite of tactical or political differences. Whether directly or indirectly, prospectively or retrospectively, their sound surrounds the event of Mueda and makes audible the deeper, broader sentiments that underwrote and sustained the specific claims brought by a small group of migrants at the door of the administration of Mueda on 16 June 1960.

To ascertain precisely the nature of the demands that the various delegations addressed to the Governor inside the closed rooms of the secretariat of Mueda (see Figure 1) is extremely complicated, considering the divergence in the protagonists' rendering of the encounter. Simon Nshusha - the only survivor of the 'group of seven' who had been sent by Vannomba to Mueda to ask permission to sell SAM cards and who was arrested as a consequence on 27 April - described the demand with the very same words in interviews given at 23 years' distance: kulidai shilambo shetu, 'to demand our country for ourselves'. ${ }^{61}$ In the four extant testimonies, Faustino Vannomba stated that the group demanded uhuru, independence, which infuriated the Governor and led to their arrest.62 Yet his only rendition of the dialogue is extraordinarily ambivalent. Not only does the conversation hinge around the meanings of return; the leaders articulate their demands only indirectly, through the voice of the crowds:

\footnotetext{
${ }^{60}$ Borges Coelho, 'Politics and Contemporary History'.

${ }^{61}$ Kudai is a Kiswahili word that describes the condition in which someone has the right to have back something from a person who owes him (borrowed money, an object, and so on). It could be translated as 'demand', 'require', 'claim'. Shilambo shetu is 'our country': as explained above, the exact territorial meaning is not specified. Simon Nshusha vehemently denied that any double talk was ever planned among Shibiliti, Vannomba and himself.

${ }^{62}$ The four testimonies are: a three-minute clip in Mueda Memória Massacre; an interview carried out by Marcos Maundumbwe, 15 February 1981, in Inhambane; an interview carried out by Estevão Jaime Mpalume upon Vannomba's return to Mueda and published in Shimakonde in the magazine Lyalosho, 3 (1990), pp. 21-5, and in Portuguese in Massacre de Mueda, pp. 29-36; a joint interview with Simon Nshusha, carried out by Harry West and Agostinho Mandumbwe in 1995, summarised in West, 'Sorcery of Construction', pp. $147-9$.
} 


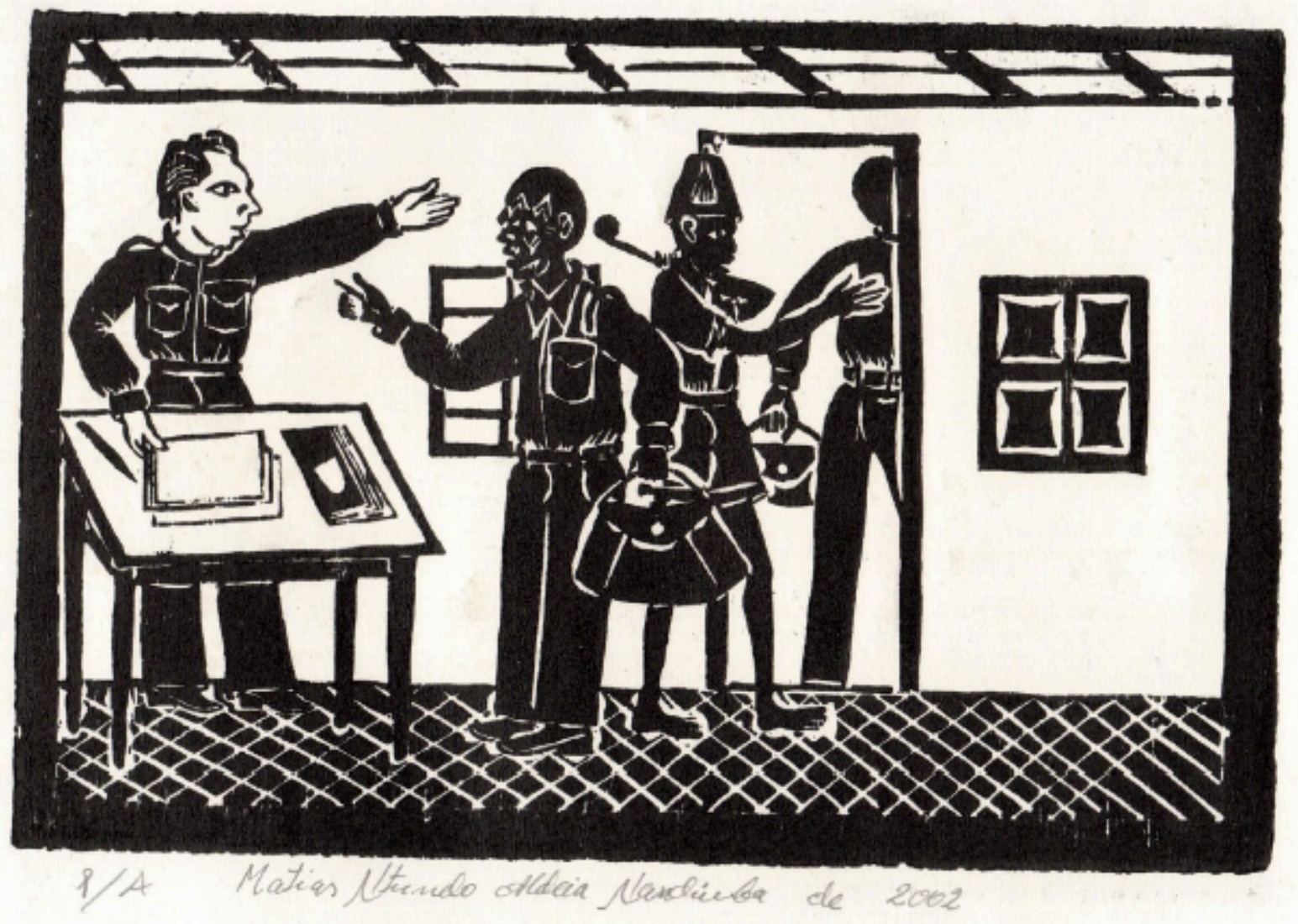

Figure 1. Faustino Vannomba addresses the administrator (Matias Ntundu, engraving on wood, 2002).

It was $3 \mathrm{pm}$ when we began speaking with the colonialists. They called first Kibiriti in the Administrator's office. The administrator began to interrogate him:

- Kibiriti, you were in Tanzania, why did you come to Mozambique?

- This is my land, said Kibiriti.

- Many return, why now there should be any difference with your return? Look out there, all those people with posters which say Uhuru. Do you know Uhuru?

- I don't know.

- What is Uhuru?

- Uhuru means freedom: independence.

- So you want independence?

- If it is to give me independence today, you should ask the crowds.

He spoke with the Governor and later the Governor sent the Administrator to call me [to] speak. They called me and the Governor asked me:

- Vanomba, didn't we tell you not to come back again?

- You told me yes. You told me not to return, to live in another country, while I have my land. For this I returned. 
- And that multitude of people - he asked again - what do they look for?

- Go ask the multitude and it will say what it came here for and what it wants. ${ }^{63}$

Shibiliti was never interviewed; neither was Nkassika Ochiva, the infamous lingwa ('tongue', interpreter) of Makua origin who mediated the encounter. Those who attended the meeting held at the hamlet of Vannomba's maternal uncle, Clemente Nandang'a Jangalia, on the eve of the massacre, say that the two spoke about independence and pleaded with everybody not to carry weapons of any kinds, because they would 'go and take the country just with this cane'. ${ }^{64}$

A bent cane (ifimbo) worn around the elbow was a symbol of independence because it was associated with Nyerere, who often carried one; the Makonde widely referred to it as uhuru. ${ }^{65}$

The archives of Portuguese secret intelligence do, however, provide incontrovertible proof that Vannomba approached the Portuguese consulate in Dar Es Salaam with the objective of demanding the return en masse of Makonde migrants to Mueda and the implantation of SAM there as a mutual help association. ${ }^{66}$ In a later account, Raimundo Pachinuapa quietly concurs. ${ }^{67}$ The Portuguese secret services took some time to assess the good faith of this demand, cast as it was in humble language and sprinkled with passionate aspersions on living conditions in Tanganyika. By the time Tiago Mulla and the SAM group of seven approached the administration, doubts were dispelled in the minds of all but the gullible consul of Portugal in Dar, who had previously provided Vannomba with visas. TMMU and SAM were considered organisations with identical objectives, both perniciously influenced by TANU nationalism; the demand of massive return, a pretext for subversive activity. Based on these reports, an order for the immediate arrest of Vannomba and Shibiliti was issued by the Governor General on 16 May and never revoked; it was not carried out upon their arrival in Mueda only on account of the administrator's cowardliness when faced with a crowd of 300 angry-looking Makonde who escorted the two leaders. 6868 The demand for the return of Tanganyikan migrants to Mozambique would remain on the political agenda of an overtly nationalist and panAfricanist MANU well into 1961.

The idea of a massive return of Makonde migrants appears to have been Vannomba's own stroke of political genius. He was the first to submit it in writing to the Portuguese consul in Dar, in February 1959, when he still belonged to TMMU.69 Its meaning should not, however, be taken for granted. To what end would Vannomba want a massive repatriation of Makonde migrants to Mueda? One possible interpretation is that he planned to use associationism as a tactic to implant subversive political organisations in northern Mozambique. According to war veteran Stanislão Dyomba, this is what Shibiliti conveyed to a restricted audience in small

\footnotetext{
${ }^{63}$ Faustino Vannomba, interviewed by Marcos Mandumbwe, Matambalale, 15 February 1981.

${ }^{64}$ Gabriel Elias Shitandala, interviewed by Paolo Israel, Mwambula, 11 June 2015. These words find a distorted echo even in Manuel Godinho's testimony, available at https://macua.blogs.com/moambique_para_todos/files/mueda_god_1960.doc, retrieved 20 August 2017.

${ }^{65}$ Reference to such canes appear throughout Portuguese intelligence and Mozambican testimonies.

${ }_{66}^{66}$ Among the great deal of documentation, see TT, PIDE/DSG, processo SR 2370/60.

${ }^{67}$ Pachinuapa and Manguedye, A Vida do Casal, 27.

${ }^{68}$ TT, Telegram 88/GOV/960, Correspondencia, Porto Amélia, SCCIM L/4/10/CD, 2/377.

${ }^{69} \mathrm{TT}$, SCCIM L/11/5/2, 77-8. The letter was written by Vannomba and signed by Tangazi Macalica, among others.
} 
meetings held in the days immediately preceding the massacre. ${ }^{70}$

Yet another song offers a more direct rendering of the meaning that the return of migrants might have had in Mueda. The song was unwittingly captured by Gerhard Kubik during an ethnomusicological foray on the site of the Imbuho mission on the eve of the armed struggle, facilitated by his friend and fellow countrywoman Margot Dias..$^{71}$ The recording sessions centred on xylophone music, initiation songs, and mapiko choirs. The choice of the location happened to be felicitous: the mapiko group from the nearby hamlet of Namau had at the time arisen to the greatest renown under the leadership of a family of migrants, the Nyushi. ${ }^{72}$ For the recording, they played fashionable songs of love and betrayal in a typical melange of Kiswahili and Shimakonde. Into this repertoire they slipped a tune of no less musical flamboyance but with an altogether different lyrical tenor:

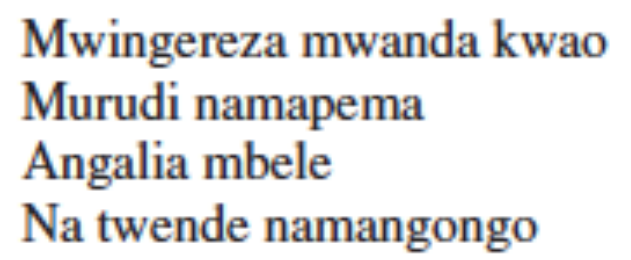

Mwingereza mwanda kwao

Murudi namapema

$\mathrm{Na}$ twende namangongo

\section{The English is going home Return in haste Look forward And let's go with the cudgels}

The decolonisation process in nearby Tanganyika is described in the continuous present, from which one can surmise that the song was composed in the time of transition between British rule and independence. The call to return is explicitly linked to political foresight and Fanonian retribution. The Namau group spread the song throughout the plateau as it travelled to dance for initiation rituals or in mapiko contests, the mask always wearing the symbolic uhuru cane. The tune was therefore widely known and sung at the time.

That the return of Tanganyikan migrants was seen in Mueda as a beacon of hope and means to rebellion is confirmed by a crucial passage of Vannomba's last testimony:

[i]n 1956 I looked for a way to get out of Tanganyika secretly, to meet with people from Mozambique and look together for a way forward. I arrived in Muatide, in the hamlet of the owner [mwene] Nandang'a and I spoke a bit with the people there. In Mwatidi I met with Clementino Nandang'a and with some people from Miteda. Two people told me: 'This is really good, but it should not begin from within Mozambique, because we are here like people who have been shut into a barrel'.

'It is necessary to open the lid [literally, "to un-lid us"]; if the lid is removed, we will come

\footnotetext{
${ }^{70}$ Stanislão Dyomba, interviewed by Paolo Israel, Nangade, 29 September 2014. The same was conveyed by João Cornelio Mandanda, interviewed by Colin Darch, Yussuf Adam and others from the CEA brigades, Mueda, 1981.

${ }^{71}$ Gerhard Kubik, Makonde recordings, Vienna Phonogrammarchiv, 1962.

${ }^{72}$ Collective interview, Namau, 15 June 2015. The group dancer was Cosme Nyusi, firstborn paternal uncle of the current President of Mozambique, Filipe Nyusi - a man with a sulphurous reputation, which would earn him the war nickname Nantova - the deathless (literally, he who doesn't bury his own shit); see F. Nyusi, Para Além do Horizonte: Enigmas a Volta do Comandante Nantova (Rio de Janeiro, Dunya, 2012); and Israel, In Step With the Times, p. 179.
} 
out'. Then they said: 'We cannot provoke the Portuguese, us who live with them; this thing should come from the outside'. I understood very well what they meant.73

The images of the cudgel and the barrel cast in a different light the dynamics of agency underlying the Mueda events: not as the initiative of 'detribalised' Africans whose eyes were opened by the experience of urban life in Tanganyika, but as a plea coming from the land - from ritual masks and lineage authority - for migrants to perform a self-sacrifice for the benefit of those who had been left behind, as if bottled. Was the idea of return conceived as a political picklock to pry the barrel open?74 Or as a cudgel? Were the return and the conditions attached to it an 'impossible demand' intended to prompt a violent refusal, thus demonstrating the inadequacy of the colonial state?75

Songs and their reverberations begin to reorient our perception away from organisational history toward symbol, feeling and imagination. The coming of various groups of migrants to knock at the door of the Mueda administration in the first half of 1960, beyond the content of the specific demands they might have posed and the dynamics of the associations around which they clustered, was met in Mueda with messianic expectations. These were expressed in several languages. One was the miraculous. The song remembers the handcuffs that broke thrice, as if they refused to imprison the saviours; but accounts from both sides also refer to Shibiliti's boasting magical invulnerability to bullets, or the ability to turn them into water with his uhuru cane. ${ }^{76}$ Similarly, Tiago Mulla had seemingly demanded of the Mueda administrator that the bicycle with which he was carried to Mueda be shipped together with him as he was sent to jail, or else the ship might sink. 77 There are metaphors of sacrifice and salvation: the barrel and the cudgel which invited the migrants; the throwing of the first stone by the merchant China; but also Vannomba's farewell to his maternal uncle and the boy who carried him on the bicycle in resigned terms: 'what we are going to ask, they are not going to give. But do not despair.

\footnotetext{
${ }^{73}$ Mpalume, 'Shitunduvangilo', p. 21. I translate from the Shimakonde text. Mpalume's translation in Portuguese coats the testimony in langue de bois (for instance, the final sentence is translated as 'I had to respect this recommendation'). The 'barrel' is also rendered as a 'bottle'.

${ }^{74}$ This finds indirect confirmation in Simon Nshusha's insistence that he was specifically chosen as an envoy by Vannomba for his tendency to lose his temper (kushimwa-shimwanga - 'to get angry-angry'). In other terms, the demand to sell SAM cards would have been a provocation for which Nshusha was demanded to perform a self-sacrifice, the consequences of which went far beyond his expectations. Nshusha, interviewed by Paolo Israel, Matambalale, 26 September 2014.

75 S. Žižek, Demanding the Impossible (London, Polity, 2013), and, closer to home, A. Kwei Armah et al. (eds), This Peasant (Dakar, Per Ankh, 2016). Godinho indeed describes the conversations - which he did not attend - as provocation. The transcript of the colonial process interprets the request for return along the same lines.

${ }^{76}$ See Nauka et al., interviewed by ARPAC team, 2 June 2010, and Godinho's testimony.

${ }^{77}$ Pachinuapa and Manguedye, A Vida, p. 28.
} 


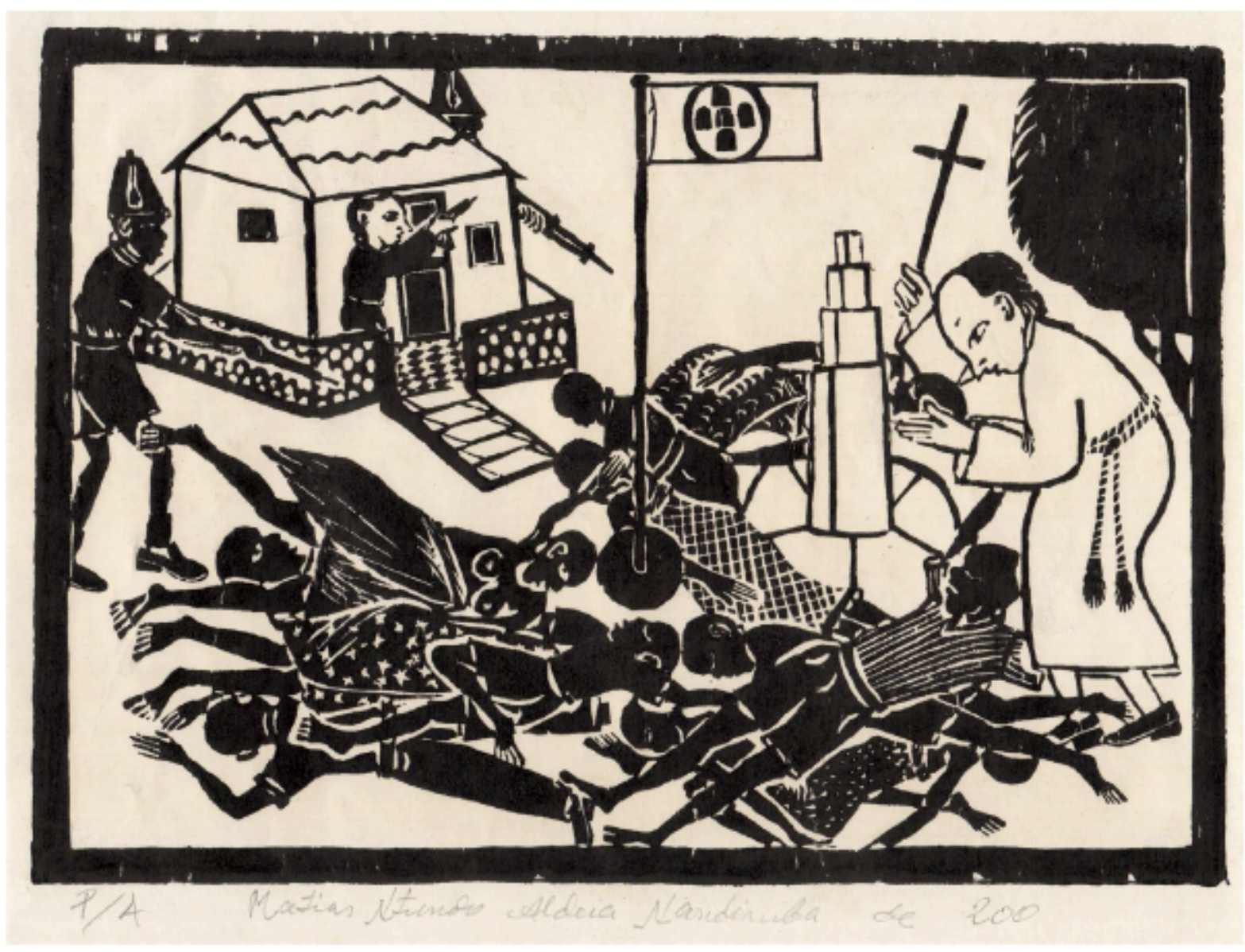

Figure 2. A priest performs the final anointing (Matias Ntundu, engraving on wood, 2002).

If I die, another Faustino will come to take up what I have initiated'. ${ }^{78}$ The crowd itself rewarded the migrants' sacrifice by offering to be collectively imprisoned together with them: 'you'd rather take us all!'79 There is the symbolism of freedom in performance and attire: the procession of bicycles and people from Matambalale to Mueda blowing lipalapanda horns and carrying uhuru canes on the arms; the bearing of inscriptions with, and chanting of, the TANU slogan Uhuru na Kazi, or just Uhuru, some even carving the word on the soles of their shoes so that the mark would be impressed on the sand; the offer by the migrant delegation to the governor of a manioc, accompanied by the invitation to go and plant it in his own land; the collective refusal to sing the Portuguese anthem and to hail the Portuguese flag. ${ }^{80}$ Nature itself contributed to the symbolic layering of the event with the storm that preceded the dramatic denouement, unusual in the heart of the dry monsoon season: omen of disaster, harbinger of change. Finally the presence of priests from nearby missions, equipped with

\footnotetext{
78 Enrique Paulo Cosme, interviewed by Paolo Israel, Matambalale, 12 June 15. Vannomba had been warned that a return to Mozambique would have been considered as an act of disobedience, and by his entourage that he would meet the same end as Tiago and Nshusha.

${ }^{79}$ Ridiculed by Adam and Dyuti as an excess of Mandanda's nationalist testimony (Adam and Dyuti, 'Falam testemunhas', p. 125), this detail finds confirmation in the official report of Post Chief Manuel António Frias of 19 June 1960.

${ }^{80}$ All these details recur across accounts and testimonies, oral and written. See, among others, A.C. Machungu, Planalto de Mueda: Seu Papel na Luta de Libertação Nacional (Pemba, Academica, 2011), pp. 36-52.
} 
holy water to anoint the dead, was seen as the sign that the massacre had been planned ahead (see Figure 2). ${ }^{81}$ The hundreds of bicycles left abandoned in front of the administration like ghosts of a broken dream, the stories about crows feasting for weeks on the corpses of those who had run for salvation in the wrong direction to fall in the vertiginous ravine of likabakobo, completed the apocalyptic tableau. The myth was not inscribed a posteriori on the event: rather the event was produced to become myth as it unfolded.

The symbolism was sustained by the unrealistic expectation that something would come out of the meeting: that 'something good' would be communicated, the country returned to the rightful owner who had 'chipped' it first, the predator flying away like a plane. All eyewitnesses coherently convey the same sense of immediacy and euphoria. As the news of the meeting was carried from hamlet to hamlet by native authorities under direct orders of the Portuguese, the rumour began to spread: we are going to get independence! Traces of this utopian misunderstanding can be detected even in the most restrained of testimonies, when the coat of officialdom is dropped for a moment: '[w]e were all anxious for the Governor to say something about the independence of the country ...'82

To what kind of independence or freedom did these expectations refer? It would be somewhat futile to ask whether this dream of independence was ethnic, national, or in between; or even to wonder if the desire for Nyerere to replace the 'white of Mueda' indexed a precise plan to integrate the region in Tanganyika. ${ }^{83}$ The symbolic dimensions of the event exceed any such interpretation. They point to a utopian idea of independence, more dreamt than organised; to 16 June as the stage of a carnivalesque feast of liberation abruptly terminated in blood. 84 'We didn't even know what Mozambique was, where it began or where it ended, and we didn't know what was independence; but that's what we wanted' - this formulation expresses the feelings conveyed by many. And it was indeed of political idealism that further generations of Frelimo militants would accuse the leaders coming from Tanganyika: 'they came with sweet words, but no real details on the how' ${ }^{85}$

The work of the Subaltern Studies Collective offers promising hunches to understand this utopian independentism. Discussing the rise of nationalism in rural India, Shahid Amin and Partha Chatterjee have pointed to the formation of ideas of sovereignty in the domain of the spiritual, in relative autonomy from the literate nationalism of the urban elites, who would drive the anti-colonial resistance through parties and ultimately take power. ${ }^{86}$ These ideas

\footnotetext{
81 This fact is noted by all eyewitnesses, official and unofficial, and features prominently in the popular memory and popular representations of the massacre.

${ }_{83}$ Raimundo Pachinuapa, in A Guerra, p. 6.

${ }^{83}$ This plan was on TMMU's agenda but apparently not on SAM's. The rumour that Nyerere might have taken over northern Mozambique as far as the Lurio river, recorded by colonial intelligence, might have sparked the rivalry between TMMU and SAM and prompted a race to be the first leader of a recognised political organisation on the territory, in the hope of being nominated governor once it was annexed.

${ }^{84} \mathrm{I}$ am referring here to Mikhail Bakhtin's utopian interpretation of the carnivalesque feast, in M. Bakhtin, Rabelais and His World, translated by Hélène Iswolsky (Bloomington, Indiana University Press, 1984).

${ }^{85}$ Ernesto Gregorio Libuda, interviewed by Colin Darch, Yussuf Adam and Anna Maria Gentili, Namau, 14 August 1981, AHM, oral history section.

${ }^{86}$ S. Amin, Event, Metaphor, Memory: Chauri Chaura, 1922-1992 (Berkeley, University of California Press, 1995); P. Chatterjee,
} 
took shape in a subaltern public sphere, especially through metaphor and rumour. In the light of this, one should not hastily dismiss the simple, oft-repeated observation that 1960 was 'the' year of independences in Africa; indeed, one should ask why would it be less 'natural' for any rural African to heed the wave of nationalist enthusiasm rippling across the continent from Ghana to Tanganyika than to espouse ethnic solidarity.

Enthusiasm and hope register as anxiety in the colonial archive. On 10 March 1959, an order was given to all Cabo Delgado administrators to put in place an intelligence network geared to detect the rise of nationalist sentiment and the influence of continental politics. ${ }^{87}$ Special attention should be paid to the imaginary impact of African nationalist movements. Nyerere is the recurring bugbear: organising meetings across the border to provoke the Portuguese administration, depicted on matchboxes, sending envoys and agents provocateurs. In a letter dated 19 May 1959, the administrator of Ibo reported a wave of panic following a rumour about 'ghost panga boats sweeping the coast with emissaries of Julius Nyerere'. ${ }^{88}$ The slogan uhuru could be heard everywhere: yelled at mapiko gatherings, as a form of salutation, even exclaimed after starting a car stuck in the mud!89 As suggested by Juakali's composition, the massacre stifled these utopian longings and suggested prudence. Padre Elias from Nangololo indeed remarked: '[a]fter the Massacre of Mueda [the] nationalist sentiment became much less direct - we want lorries, we want shops, etc. Not we want independence'. ${ }^{90}$

The utopian, carnivalesque atmosphere of 16 June is well conveyed in one of the few extant accounts provided by a non-Portuguese eyewitness in the immediate aftermath of the events a 'primary discourse', in Ranajit Guha's definition. ${ }^{91}$

The man called Nambanyani was capataz (foreman) in a peanut farm belonging to a Portuguese near Mwatidi when the first French missionaries arrived on the plateau in 1924; as an influential young man he was asked to provide support, which he agreed to do. As time went by, Nambanyani was drawn into the missionaries' circles, always accompanying the fathers in their activities, learning to read and write, and eventually becoming a literacy teacher. In 1927 he received the first medal of catechumen, and in 1928 he was baptised with the iconic name of Simon Matola, becoming thereafter the mission's factotum..${ }^{22}$ In 1959 Matola spent some time in Tanganyika and met Shibiliti and Vannomba. When he came back to Muidumbe he began to scout for potential members the Makonde Association (the name initially given to SAM); as a consequence he was jailed for three days and stripped of his job as cotton-field foreman. On 15 June Matola wrote to the leaders two passionate letters containing precise indications

The Nation and Its Fragments: Colonial and Postcolonial Histories (Princeton, Princeton University Press, 2003).

${ }^{87}$ Communicated through the circular 158/59/GOV, issued under the instructions of the metropolitan government.

${ }^{88}$ AHM, Adminstração do Distrito de Porto Amélia, A/42/58-60 (box 293).

${ }^{89}$ It should be noted that colonial intelligence consistently translated the word uhuru as 'independence'.

${ }^{90}$ Padre Elias, interviewed by Colin Darch, Jacques Depelchin and Anna Maria Gentili, Colin Darch archive, Cabo Delgado notes.

${ }^{91}$ R. Guha, 'The Prose of Counter-Insurgency', in R. Guha and G. Chakravorty Spivak (eds), Selected Subaltern Studies II (Delhi, Oxford University Press, 1988), pp. 45-88.

92 R.C. Cazzaniga, Missão de Nangololo: Actos dos Apóstolos do Século XX (Maputo, Paulinas, 1995), pp. 18ff. Matola is the Shimakonde name for the palmatória, an instrument of punishment with which disobedient children and colonial subjects would be struck on the palm of the hands. 
of the native authorities and individuals who were against them. ${ }^{93} \mathrm{He}$ then went on to attend the meeting, despite the missionaries' advice to the contrary. 94 Ten days later, he wrote a letter to his sons relating the events:

[c]ome two Makonde boys from Tanganyika who want to talk with the Governor from Porto Amélia. Say that Mr Governor should you not deal with the Maconde, be well as in the land of Tanganyika, then go back home to your land Portugal. They would meet, Macondes, Macondões, Macondinhos, and Mr Governor came out of the office and began to speak thus:

'Look Macondes, I already responded to your demands. Plantation of sisal, they are going to increase the salary, Indians of the shops, they are going to raise the price of maize, or peanuts, of beans, the roads we are going to fix them [...] Shit! The Makonde when they heard this they all yelled: Go away! Go away! The bitch who gave birth to you, the bitch who gave birth to you, you want to swindle us, others threw stones, the Governor backed and $\mathrm{Mr}$ Secretary received him, and Mr Chief received him. Shit! The soldiers are nearby with guns, they fired three times, about 30 died, in the hospital there were many [...]95

All because those two boys from Tanganyika spoke thus: Government of Portugal, when you don't want to treat us well, our land be like Tanganyika, we are going to call the Government of Tanganyika come here to the Maconde and rule us. We must just call Mr Dr Julius Nyerere from Tanganyika and he can speak with the government of America, and of Russia, and of German, and of Chinese, come here and that's done. All groups of the Maconde shouted: we want so, we want so, spoke Faustino and Kibiriti, two boys from Tanganyika. ${ }^{96}$

The colourful Portuguese conveys the carnivalesque atmosphere of the meeting; the utopian expectation that nations on the opposite front of a cold war would intervene and deliver Mozambique from its heinous master; the raw rage of kupajola reflected in the 'go away' and 'son-of-a-bitch' (puta cumpariu). The content of the demands of the two 'boys from Tanganyika' are presented as blackmail. If you don't 'treat us well', 'make our land be like Tanganyika' - a very allusive formulation, since that territory was on the path to independence - then we'll summon Julius Nyerere and all the worldly powers we can think of to send you back home. Not only the desire for Nyerere to rule, but for the white of Mueda to die has left a trace in these lines. For while I am inclined to render the recurring ungrammatical word Orra! as porra ('shit' - literally, 'cum'), the curator of Bishop Garcia's archive, where the letter was found,

\footnotetext{
${ }^{93}$ TT, Tradução dum documento encontrado em posse do indígena Faustino Vanombe, SCCIM, L/4/10/CD 3/291.

${ }^{94}$ It appears that the missionaries at Nagololo had a hunch about the outcome and discouraged their personnel from going. P.J. Seguro, interviewed by Paolo Israel, Mwambula, 12 June 2015.

95 The same figure of 30 is quoted in Godinho's account. Enrique Cosme, who hid under the jeep that was to carry Shibiliti and Vannomba away, and was formed to pile up the dead, referred to a few dozen (interview, Matambalale, 13 June 2015. This, incidentally, demonstrates that nationalist eyewitnesses are very well able contradict the official version). In contrast to Cahen's version, General Silvestre timidly admitted that the Portuguese soldiers on the jeep lost control of the situation and fired the machine gun into the crowds ( $A$ Guerra, p. 6 and Televisão Indendente); this is confirmed by Freita's official report. The issue of how many tumbled to their deaths in the likabakobo ravine is hard to assess. The ravine is somewhat removed from the site, but it is sudden and precipitous; one can imagine a group of people not familiar with the location running there in high grass and falling before realising the drop, especially considering that the streets of Mueda were packed on the day. But overall, the issue of the exact number of the dead is less significant than the symbolic meaning of the event. Were there not 'only' 69 dead at Sharpeville?

${ }^{96}$ J. dos Santos Garcia, A Guerra dos Macondes (Lisbon, Tipográfica das Missões, 2009), pp. $26-7$.
} 
The migrants who 'un-lid the barrel' of Portuguese colonialism spent 14 years in prison, first on the torture island of Ibo, then in southern Mozambique. When they emerged, broken and alienated from the political processes they initiated, they were never awarded the honours they deserved. As with all political prisoners, they were marked by the suspicion of collaboration and a lack of exposure to the purifying fires of the armed struggle. 98 Vannomba and Shibiliti were transferred to different districts of the province of Inhambane, far away from their homes. Shibiliti died in Inhambane in 1977, as if in exile. Vannomba returned to Mueda only in 1990 and died there five years later, embittered and poor. The survivor Nshusha was honoured only in the wake of the 5oth anniversary of the massacre; when called upon to make a speech in the presence of the new Makonde president, Filipe Nyusi, for the celebrations of the 55th anniversary, the staggering, half-blind old man concluded by admonishing: 'the mushrooms that grow on trees [overnight], do not want them. They don't taste good'.

The horrors of torture in Portuguese colonial prisons have been exposed in a small book of testimony with forensic precision. 99 What were the feelings, fears and hopes of the prisoners in the long years of physical and political isolation? Juakali the song-master was arrested because his knowledge of song was considered by an eavesdropping native policeman to be a signal of subversive activity. The songs he composed about his time in jail highlight private, rather than political, preoccupations, such as the disappointment in his elder son, who refused to look for him in jail:

\footnotetext{
97 A.A. Nascimento, D. José dos Santos Garcia: Testemunho e Memória (Lisbon, ARM, 2011), p. $131 \mathrm{n} 171$.

${ }^{98}$ H. West, 'Voices Twice Silenced: Betrayal and Mourning at Colonialism's End in Mozambique', Anthropological Theory, 3,3 (2003), pp. $343-65$.

99 Anon., Tortura na colónia de Moçambique: 1963-1974 (Porto, Afrontamento, 1977); also 'Dossier PIDE/DSG: Do Ibo a Vila Algarve', Tempo, 196 (1974), pp. 12-15.
} 
Naulange kutangadika

Mwanangu nangu nintangadike baba Juakali

Ninankumbukila ngulyona kenga baba

nammwona kavili

Nnemba shonde

Nindyuka liduva limo ngwaloka ku-shikola

Ndauka nikannole baba nkalaboshi andifungiwa

Ninankumbukila ngulyona kenga baba nammwona kavili

Remishio langale' tuke kaka wako

Nikannole baba nkalaboshi andifungiwa

José andibanganga na kulidyuka

Tatake kumpata abali andifungiwa

Ankushidi kunammula kwikala

Atamwa kwida kunnola kumpalakedya

José kwida

Tatake ankadidye mwanda wamalilidye

Andijaligwa kwa ibati

Kwigwiti' vila

Tatako andipakiligwa
Let me tell you, I complain

I complain about my own son, father Juakali

When I think about him it looks like my father I won't see him again

Boy, woe

One day coming back from school I went

Looking for my father, they locked him in jail

When I think about him it looks like my father I won't see him again

Remigio [said] let's go ahead, brother

To look for father in jail where he's locked

José is naughty and foolish

As he hears the news, his father they took him

He does worse, he decides to stay

He doesn't want to come see him, bring him back

José comes

He met his father when his travel was already over

Good luck

He just heard

Your father has been carried away ${ }^{100}$

100

But it was another song that prisoners in Ibo intoned, bereft of all hope, as they gazed northwest over the waves and the mangroves:

\author{
Njungu Caetano, Caetano, Caetano \\ Tummwamba njungu Caetano \\ Kwaloka kwao ku-Lishiboa \\ Ankutushema vangwele wetu \\ Twikalenge namushilambo \\ Shilambo ashi shetu \\ Shilambo ashi sha-Moshambiki \\ Wako kwetu mwiu \\ Kwetu Mweda atwona kavili \\ Kwetu kulaya kwetu \\ Kwetu kwambone \\ Kwetu kuMweda atwona kavili \\ Caetano kutungwa wetu \\ Natuwika pa-Ibo \\ Kwetu ku-Mweda atwona kavili \\ Caetano kutungwa wetu \\ Nakujela Mashava \\ Kwetu kuMweda atwona kavili
}

\author{
White Caetano, Caetano, Caetano \\ We speak of the white Caetano \\ He came from his land, Lisbon \\ $\mathrm{He}$ is calling us monkeys \\ Us who stayed in the country \\ This country is ours \\ This country of Mozambique \\ You, our home truly \\ Our home Mueda we won't see it again \\ Our home is overseas our home \\ Our home is good \\ Our home Mueda we won't see it again \\ Caetano imprisoned us \\ And brought us to Ibo \\ Our home Mueda we won't see it again \\ Caetano tied us \\ And threw us in Machava \\ Our home Mueda we won't see it again ${ }^{101}$ \\ 101
}

\footnotetext{
${ }^{100}$ Recording, 4 August 2008. The song continuously changes voice and point of view. Juakali had two other compositions about jail in his repertoire: one, a farewell to his wives; the other, a humorous tale about eating a dead crow together with his captors on the way to jail.

${ }^{101}$ Gabriel Elias Shitandala, interviewed by Paolo Israel, Mwambula, 11 June 2015. The song was sung by prisoners in Ibo and Machava during the time of work and when they danced mapiko. The mention of Caetano does not imply that the song was composed after 1968 .
} 


\section{Acknowledgements}

Early versions of this article were presented at the Arquivos e Investigação Cientifica conference (Maputo, 18 August 2015); the Seminario de Pesquisa na História da Luta de Libertação (Maputo, 9-11 September 2015); the South African Contemporary History and Humanities Seminar (Cape Town, 19 April 2016); the Resistance and Empire conference (Lisbon, 26-29 June 2016); the Politics of Armed Struggles conference (Johannesburg, 23-25 November 2016); and the Centro de Estudos Africanos seminar (Maputo, 30 March 2017). Research for this article was made possible by funding granted by the University of the Western Cape. I thank Yussuf Adam, Jocelyn Alexander, Michel Cahen, João Carlos Colaço, Colin Darch, Aidan Erasmus, Carlos Fernandes, Jung Ran Forte, Patricia Hayes, Estevão Jaime Mpalume, Davety Mpiuka, Frank Ntaluma, Janne Rantala, Wilton Schereka, Raquel Schefer, Ross Truscott and Harry West for their insightful comments. A special thanks to Fidel Mbalale for the finest ever oral history motorcycle trip. 